\title{
Biodiversity of Pearl Millet [Pennisetum glaucum (L.) R. Br.] in Southern Algeria (Hoggar Region)
}

\author{
Mohamed Lemgharbi1,2*, Badreddine Belhadi', Rachid Souilah', Ladjel Terbag1, \\ Djafaar Djabali ${ }^{1}$, Boubekeur Nadjemi ${ }^{1}$ \\ ${ }^{1}$ Laboratoire d'Etude et de Développement des Techniques d'épuration et de Traitement des Eaux et Gestion \\ Environnementale, Ecole Normale Supérieure de Kouba, Alger, Algérie \\ ${ }^{2}$ Laboratoire de Biochimie, Département de Biologie, Ecole Normale Supérieure, Alger, Algérie \\ Email: "Lemgharbim@yahoo.com
}

Received 28 July 2016; accepted 26 August 2016; published 29 August 2016

Copyright (C) 2016 by authors and Scientific Research Publishing Inc.

This work is licensed under the Creative Commons Attribution International License (CC BY).

http://creativecommons.org/licenses/by/4.0/

c) (7) Open Access

\begin{abstract}
Despite the areas restriction reserved for pearl millet cultivation in Hoggar region, there is an important diversity, which has occupied an essential place in the inhabitants' diet. For a better knowledge of its biodiversity, seven sites were prospected during the plant maturation period. The morphological and cytological study was undertaken on the basis of the descriptors parameters of the International Crops Research Institute for the Semi-Arid Tropics (ICRISAT). The most widely varied variables were the Height of the Plant (HP), Stem Diameter (ST), Panicle size; Length (PL), Width (PW) and Color (PC). While very low variation was noted in $3^{\text {rd }}$ leave dimensions; Leaf Length (LL), Leaf Width (LW), Number of Nodes (NN) and Seed Form (SF). Therefore, local millet (MLH.epc, MLH.Z I $_{1}$ and some domesticated (MDH. Saf, MDH.S) appeared as the best groups, based on their panicle characters and seed nutritional quality. Agro-morphological changes detected in this study, show that the majority of millet domesticated (MDH. Saf. P, MDH. Sepl) are generally, classified in second place and used as fodder in the Hoggar region.
\end{abstract}

\section{Keywords}

Biodiversity, Hoggar, Morphology, Panicle, Pearl Millet

\footnotetext{
${ }^{*}$ Corresponding author.
}

How to cite this paper: Lemgharbi, M., Belhadi, B., Souilah, R., Terbag, L., Djabali, D. and Nadjemi, B. (2016) Biodiversity of Pearl Millet [Pennisetum glaucum (L.) R. Br.] in Southern Algeria (Hoggar Region). American Journal of Plant Sciences, 7, 1673-1684. http://dx.doi.org/10.4236/ajps.2016.712158 


\section{Introduction}

Pearl millet has an ability to grow in environments of low and erratic rainfall, high temperature and low soil fertility [1], so it has a wide geographic distribution and phenotypic diversity. It is a cereal fundamental for many people in semi-arid areas of Africa and Asia [2] [3]. It was probably introduced during the eighth century in North Africa, where it is grown for seed production [4]. Millet [P. glaucum (L.) R. Br.] is a Poacea family, whose growing cycle varies from 48 to 120 days, characterized by a panicle that takes many forms. It is a sexual plant, diploid $(2 \mathrm{n}=2 \mathrm{x}=14)$ by hermaphrodite flowers out crossing [5] with a female flowering earlier than flowering male and pollination by wind. This cereal avoids the drought that characterizes its culture area by closing stomata, lower leaf surfaces and the development of root system [6].

The diversity of morphological traits was evaluated by many authors; for example, according to the length/ width ratio of seeds [7] [8] or through other morphological characters it has strong heritability [9]. The domestication exchanges can be positive, allowing maintaining an important source of diversity among the cultivated form, or negative, for example diffusion with non-controlling genes transformed by genetic engineering [10].

In South of Algeria (Sahara), especially Hoggar region, which is characterized by a typical desert climate, scalding and dry, the high temperatures of summer contrasted with those winters where it can freeze, rain is rare. However, these inhospitable conditions are less extreme than in the rest of the Sahara [11]. Despite these hard local climatic conditions, local millet maintained its original morphological diversity for centuries. They could accumulate significant genetic diversity between populations. Pearl millet [P. glaucum (L.)] is a cereal named as Dokhen (Arabic); the local name is Ineli (Targhi) or Bechna (Dialect). Originally, it's from West Africa, particularly from the area of the north-east of the Senegal River. Its culture should produce seeds and fodder [12]. While in developed countries it is grown for forage, livestock and an ingredient in the animal feeds [13].

This study aims to assess the biodiversity of pearl millet populations, whether cultivated or wild in this region (Hoggar), to use intensive selection criteria efficiently, and enrich our present knowledge about the local genetic resources of these cereals.

\section{Material and Methods}

\subsection{Area Descriptions}

The Hoggar covers an area of approximately 540,000 $\mathrm{km}^{2}$ (Quarter of the Algeria total area). It includes Tamanrasset town and the surroundings: Abalessa, In Amguel, Amsel and Tabrakat (Figure 1). It is an important crossroads of trade with the neighboring countries of the Sahel.

The region geomorphology distinguishes by Tidikelt plateau (in Salah region) in the North, covered with sand and the harsh climate. Hoggar (Ahaggar) South Mountain where temperatures are milder. The province is home to the highest peak in Algeria, Mount Tahat to $3003 \mathrm{~m}$ above sea level located in the Hoggar Mountains. It is located between the $12^{\text {th }}$ and $25^{\text {th }}$ parallel of the northern hemisphere, straddling the Tropic Cancer, and the $3^{\text {rd }}$ and $6^{\text {th }}$ meridian east of Greenwich. The Hoggar consists mainly of volcanic rocks, desert of rocks, erosion has shaped a stunning landscape while sharp peaks, due to a less extreme than the rest of the Sahara, and it is an important refuge for some plant and animal species. On the ecological point of view, it can be differentiated from the rest of the Sahara, generally, the soils encountered in this region reveal somewhat or very advanced, following insufficient moisture, these soils are zonal crude [14], with profiles poorly differentiated or non-existent [15].

Generally, precipitation occurs in May to September, following the rise of Sahara intertropical front and the extreme south of Algeria. In his general conclusions about the main characters rainy Saharan, Dubief (1959) [16] reported that, they are rare and generally low quantitative importance. However, the Hoggar climate, type "little tropical Mediterranean”, is more desert by low rainfall, that by their rarity. As for the thermal regime, it is very mixed, influenced by altitude and latitude. On average the month of June is the hottest of the year with $40^{\circ} \mathrm{C}$ in Tamanrasset, $1395 \mathrm{~m}$ altitude and $28^{\circ} \mathrm{C}$ in Assekrem to $2728 \mathrm{~m}$, and January the coldest month, with temperatures approaching absolute every low temperatures $\left(-13.5^{\circ} \mathrm{C}\right.$ in 1993$)$ [11].

The study of the flora and vegetation shows the existence of specific Sahara species (Artemisia, Tamarix, Ficus, Panicum, Palm, Ziziphus...) [17] [18], which are added Mediterranean elements (Olive, Myrtle, Lavender...) and tropical (Acacias, Calotropis, Balanites...) [19], [20]. However, the uniqueness of this plant is its poverty indisputable because of extreme weather conditions. Also, due to its high elevation, the Hoggar is less warmer 


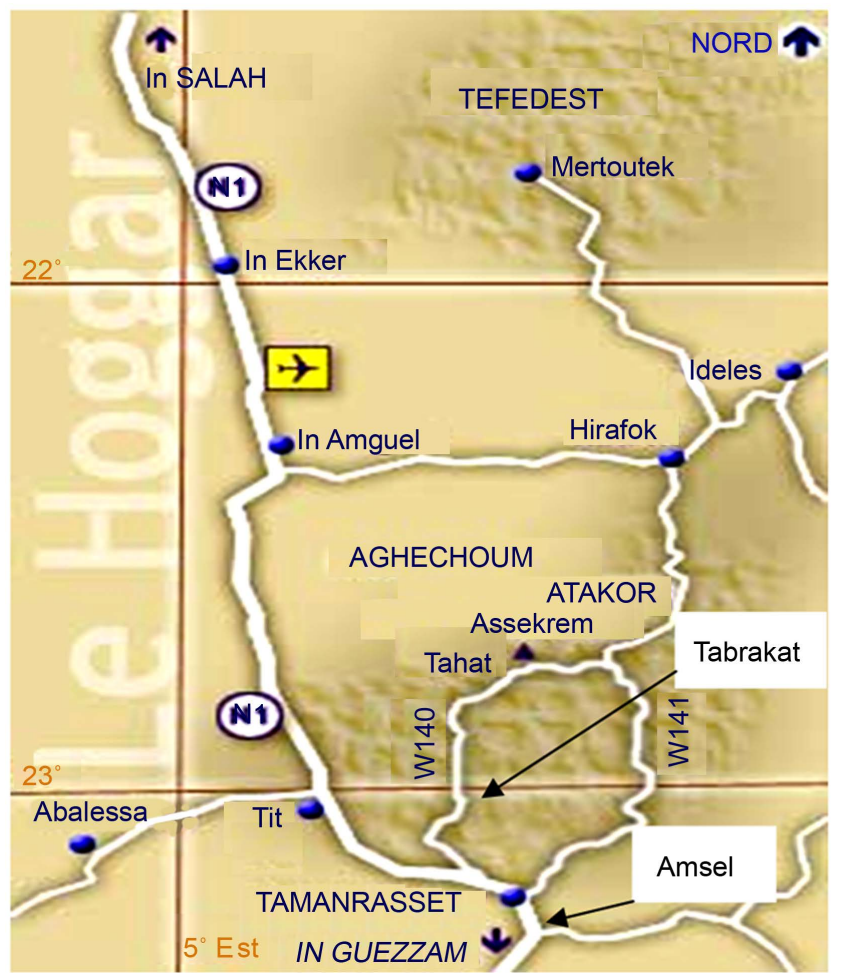

Figure 1. Hoggar card (http://imzadanzad.com). Tidikelt: in Salah region and its surroundings.

and less arid than desert plain, served refuge for plants that are excluded from it, including relics to Mediterranean or Tropical strains that once these reached massive thanks to the wetter periods. It shows a high level of endemism, which increases with altitude [12].

The followed way for millet groups identification, is from the North- east of Tamanrasset (In Amguel, 130 $\mathrm{Km})$ to Abalessa $(100 \mathrm{~km})$ Nord-west of the region, as traditional old fields. We were passed through intermediate sites, Amsel $(20 \mathrm{~km})$ South-west of Tamanrasset town and Tabrakat $(4 \mathrm{~km})$ Est, as new and modern fields, where the farmers apply modern irrigation systems. A total distance of $255 \mathrm{~km}$. seven groups of traditional and new fields finding in that way were inspected in November 2008, 2010 and October 2011 during panicles maturation period of plant, data location of sites visited are recorded (Table 1).

\subsection{Experimental Material}

The experimental material is composed of 09 millet accessions, cultivated in different sites of Hoggar region. There are two types of fields, Traditional in Abelessa; very old soil with a traditional irrigation system, (Traditional wells). Besides, there are new fields (Amessel, In Amguel and Tabrakat) where the farmers use generally, a modern irrigation (Drip system) and there is a new rich soil too. Therefore, morphological characterization was only carried out for those accessions that performed well under field condition during cropping season (Table 2).

\subsection{Methods}

\subsubsection{Morphological Study}

Data were collected by search members and a supervisor with the help of local farmers. Descriptive study; qualitative characters and quantitative measures of millet morphological parameters, were realized at plant maturation stage in the different fields of sites according to Andrews and Kumar (1992) [21] of millet descriptors, for example: Plant Height (PH), Number of Nodes (NN) and Leaves (LN), the third leaf dimensions; Length (LL) Width (LW) and Panicles Colors (PC) at maturation (Table 3), the color being determined based on Royal Horticultural Society (RHS) color codes [22]. 
Table 1. Sites visited in Hoggar region during cropping season (November 2008, 2010 and October 2011).

\begin{tabular}{|c|c|c|c|c|}
\hline Sites & $\begin{array}{c}\text { Distance (km) } \\
\text { (From Tamanrasset center) }\end{array}$ & $\begin{array}{l}\text { Geographical } \\
\text { Position }\end{array}$ & Altitude (m) & Site characteristics \\
\hline $\begin{array}{l}\text { Abalessa } \\
\text { (Wade Ighi) }\end{array}$ & $100 \mathrm{~km}$. & $\begin{array}{l}22^{\circ} 50^{\prime} 38 \mathrm{~N} \\
004^{\circ} 50^{\prime} 24 \mathrm{E}\end{array}$ & $897 \mathrm{~m}$ & Traditional fields \\
\hline $\begin{array}{c}\text { Abalessa } \\
\text { (Oulad Mouloud) }\end{array}$ & 100 km. Norde-west & $\begin{array}{l}23^{\circ} 41^{\prime} 12 \mathrm{~N} \\
004^{\circ} 50^{\prime} 26 \mathrm{E}\end{array}$ & $897 \mathrm{~m}$ & Traditional fields \\
\hline $\begin{array}{l}\text { In Amguel } \\
\text { (Abtoul) }\end{array}$ & 130 km. Nord-est & $\begin{array}{l}23^{\circ} 41^{\prime} 12 \mathrm{~N} \\
005^{\circ} 08^{\prime} 19 \mathrm{E}\end{array}$ & $1431 \mathrm{~m}$ & New fields \\
\hline $\begin{array}{l}\text { Tamanrasset } \\
\text { (Bab. Ezouar) }\end{array}$ & $\begin{array}{l}\text { Tamanrasset centre } \\
\text { (Ouad DNC.) }\end{array}$ & $\begin{array}{l}22^{\circ} 52^{\prime} 38 \mathrm{~N} \\
004^{\circ} 50^{\prime} 24 \mathrm{E}\end{array}$ & $896 \mathrm{~m}$ & New fields \\
\hline Tabrakat & $4.5 \mathrm{~km}$. Est & $\begin{array}{l}22^{\circ} 47^{\prime} 55 \mathrm{~N} \\
005^{\circ} 33^{\prime} 26 \mathrm{E}\end{array}$ & $1411 \mathrm{~m}$ & New fields \\
\hline $\begin{array}{c}\text { Tabrakat } \\
\text { (Thult Echioukh) }\end{array}$ & $5 \mathrm{~km}$. Est & $\begin{array}{l}22^{\circ} 48^{\prime} 41 \mathrm{~N} \\
005^{\circ} 35^{\prime} 02 \mathrm{E}\end{array}$ & $1428 \mathrm{~m}$ & New fields \\
\hline Amsel & $20 \mathrm{~km}$. South-west & $\begin{array}{l}22^{\circ} 48^{\prime} 41 \mathrm{~N} \\
005^{\circ} 35^{\prime} 02 \mathrm{E}\end{array}$ & $1428 \mathrm{~m}$ & New fields \\
\hline
\end{tabular}

Table 2. Local appellations of millet accessions with their collection sites in Hoggar region.

\begin{tabular}{|c|c|c|c|c|}
\hline $\mathbf{N}^{\circ}$ & Millet accessions & Code & Locality & Status \\
\hline 01 & Bechna Beldia (Local millet, short panicle) & MLH.epc & Tamanrasset (Bab Ezzouar) & Local Millet \\
\hline 02 & Bechna Beldia Saffra (Local Yellow millet) & MLH. Saf & Tamanrasset (Bab Ezzouar) & Local Millet \\
\hline 03 & Bechna Beldia Khahla (Local Black millet) & MLH.N & Tamanrasset (Tabrakat, Thult Echioukh) & Local Millet \\
\hline 04 & Bechna Beldia Zergha (Local Blue millet1) & MLH.Z $Z_{1}$ & $\begin{array}{l}\text { Abalessa (Zaouia, Oued Ighi) } \\
\text { Ain M'guel (Abtoul) }\end{array}$ & Local Millet \\
\hline 05 & Bechna Beldia Zergha (Local, light Blue millet 2) & MLH.Z $Z_{2}$ & $\begin{array}{l}\text { Abalessa (Oued Ighli), } \\
\text { Ain M'guel (Abtoul) }\end{array}$ & Local Millet \\
\hline 06 & Bechna Saffra, lamchaara (Hairy yellow millet) & MHD. Saf. P & Abalessa (Zaouia, Oued Ighi) & $\begin{array}{l}\text { Domesticated } \\
\text { (Tidikelt) }\end{array}$ \\
\hline 07 & Bechna Saffra, Touat (Yellow millet) & MHD. Saf & $\begin{array}{l}\text { Abalessa (Zaouia, Oued Ighi), } \\
\text { Tamanrasset (Bab Ezzouar ) }\end{array}$ & $\begin{array}{l}\text { Domesticated } \\
\text { (Tidikelt) }\end{array}$ \\
\hline 08 & Bechna Essoudan (Soudan millet, long panicle) & MHD. SepL & Tamanrasset (Tabrakat, Bab Ezzouar) & $\begin{array}{l}\text { Domesticated } \\
\text { (Soudan) }\end{array}$ \\
\hline 09 & Bechchna Essoudan (Soudan millet) & MHD. S & Tamanrasset (Bab Ezzouar) & $\begin{array}{l}\text { Domesticated } \\
\text { (Soudan) }\end{array}$ \\
\hline
\end{tabular}

Table 3. Quantitative characters recorded in the study sites along with their codes and descriptions.

\begin{tabular}{|c|c|c|}
\hline Quantitative characters & Codes & Descriptions \\
\hline Plant Height (cm) & PH & Height of the main stem from the ground to the tip of the main panicle \\
\hline Number of Nodes (count) & $\mathbf{N N}$ & Number of nodes on the main stem (Plant) \\
\hline Leafs Number (count) & $\mathbf{L N}$ & Number of leafs on the main stem (Plant) \\
\hline Stem Diameter (mm) & SD & Diameter measured on the third internodes from the ground surface \\
\hline Panicle Length (cm) & PL & Length of the panicle from its base to tip \\
\hline Panicle Width (mm) & PW & Width of panicle in natural position at the widest part \\
\hline Leaf Length (cm) & $\mathbf{L L}$ & Length of the third leaf from the flag leaf \\
\hline Leaf Width (mm) & $\mathbf{L W}$ & Width of the third leaf \\
\hline
\end{tabular}

\subsubsection{Cytological Study}

The characterization study and evaluation of millet panicles and seeds collected from different sites were conducted in order to use a descriptive and cytological study based on the parameters of The International Board for Plant Genetic resources (IBPGR) and ICRISAT descriptors [22]. Concerning Panicle Form (PF), Panicle Setae 
(PS), type of Seed Envelop (SE) and Seed Form (SF) (Table 4). Endosperm texture was defined as the proportion of corneous relative to floury endosperm in the grain, which was determined subjectively by viewing sectioned kernels using a stereomicroscope, and comparing them to sorghum standards [23]. The kernels were classified as corneous, intermediate or floury [24]. The moisture analysis content was carried out according to AACC methods 44-15A [25]. For the main millet groups (local and domesticated) where realized in laboratory.

\subsubsection{Statistical Analysis}

The qualitative and quantitative data of accessions millet were organized by four repetitions and analyzed by Analysis of Variance (ANOVA). Differences in mean values were assessed at the 0.05 probability level using least significant difference (LSD) method. SPSS. Statistics version 17.0 Logical.

\section{Results and Discussion}

\subsection{Morphological Parameters}

In fact, development and yield of pearl millet were markedly affected by temperature during plant growth: vegetative, stem elongation, and grain development [26]. High morphological variation was recorded among the 9 accessions of pearl millet [P. glaucum (L.)] from different sites study of Hoggar region, Despite the availability of the same field conditions, The most variations were observed in the height plant (HP) of the introduced millet, from 1.74 to 1.79 m (MHD.S and MHD.S epL) compared with local millet (1.12 - $1.64 \mathrm{~m}$ ) (Table 5). Many researchers found that height plant generally, decreased with delayed planting [27].

Table 4. Qualitative characters recorded in the study site.

\begin{tabular}{|c|c|c|}
\hline Qualitative characters & Codes & Descriptions \\
\hline Panicle Color & PC & Color of panicle in maturity on the main stem (Plant) \\
\hline Panicle Form & $\mathbf{P F}$ & Form of panicle in maturity \\
\hline Panicle Setae & PS & Setae on the main panicle \\
\hline Seed Number in Spikelet & SNS & Number of seeds in Spikelet in panicle maturated \\
\hline Seed Envelop & $\mathrm{SE}$ & Natural Position of seed envelop \\
\hline Seed Form & SF & Form of seed in maturity \\
\hline Seed Color & SC & Color of seed in maturity \\
\hline Seed Weight 1 Litre (g) & SW1L(g) & Weight of one liter volume of seeds in gram \\
\hline Thousand Seed Weight & TSW(g) & Weight (g) of 1000 seed taken from matured panicle at $20^{\circ} \mathrm{C}$ \\
\hline Proportion of the Floury Endosperm & PFE & Proportion (\%) of floury endosperm in seed (section) \\
\hline
\end{tabular}

Table 5. Pearl millet quantitative characters of Hoggar region during cropping season (mean \pm standard deviation, $n=4)$.

\begin{tabular}{|c|c|c|c|c|c|c|c|c|c|}
\hline & MLH.epc & MLH. Saf. & MLH.N & MLH.Z 1 & MLH.Z 2 & MHD. Saf. P & MHD. Saf. & $\begin{array}{c}\text { MHD. } \\
\text { SepL }\end{array}$ & MHD.S \\
\hline$H P(c m)$ & & & & & & & $1.12 \pm 0.01$ & .11 & 1.7 \\
\hline $\mathbf{N N}$ & $09.5 \pm 0.06$ & $08 \pm 0.35$ & $8.66 \pm 1.24$ & & $09 \pm 0.32$ & $08 \pm 0.23$ & $08 \pm 0.33$ & $11.25 \pm 2.27$ & $70 \pm 0.66$ \\
\hline NL & $09.5 \pm 0.06$ & $09 \pm 0.15$ & $9.33 \pm 0.22$ & $10 \pm 1.29$ & $10 \pm 1.25$ & $09 \pm 0.23$ & $09 \pm 0.13$ & $12.75 \pm 1.91$ & $111.66 \pm 1.24$ \\
\hline $\mathrm{SD}(\mathrm{mm})$ & $10.23 \pm 0.26$ & $9.80 \pm 0.15$ & $12.36 \pm 0.65$ & $8.25 \pm 1.72$ & $8.24 \pm 1.52$ & $9.50 \pm 0.15$ & $9.71 \pm 0.25$ & $16.64 \pm 2.52$ & $211.21 \pm 0.06$ \\
\hline PL (cm) & $11.05 \pm 1.00$ & $13.11 \pm 0.61$ & $12.83 \pm 0.38$ & $7.16 \pm 0.05$ & $7.14 \pm 0.04$ & $11.96 \pm 0.71$ & $12.16 \pm 0.71$ & $46 \pm 0.5$ & $25.5 \pm 0.16$ \\
\hline PW (mm) & $46.01 \pm 2.83$ & $32.11 \pm 1.27$ & $34.02 \pm 1.93$ & $22.17 \pm 1.38$ & $22.12 \pm 1.28$ & $32.19 \pm 1.27$ & $31.11 \pm 1.37$ & $43.52 \pm 3.79$ & $61.73 \pm 1.04$ \\
\hline L.3L (cm) & $40.61 \pm 0.38$ & $36.12 \pm 0.48$ & $46.94 \pm 3.56$ & $37.43 \pm 1.81$ & $36.46 \pm 1.61$ & $34.14 \pm 0.68$ & $35.11 \pm 0.58$ & $47.5 \pm 1.5$ & $46.83 \pm 1.56$ \\
\hline W.3L (mm) & $38.28 \pm 2.90$ & $31.50 \pm 1.12$ & $32.23 \pm 2.44$ & $23.46 \pm 0.76$ & $24.04 \pm 0.56$ & $28.80 \pm 1.11$ & $29.50 \pm 1.16$ & $47.20 \pm 1.23$ & $338.60 \pm 1.07$ \\
\hline
\end{tabular}


In addition, environmental conditions affected panicle size on the main stem and yield on tillers in the same sense [28]. Found that panicle length was maximized between 5 and 17 May. So, panicles colors (PC), panicle length (PL). These are the qualitative characters and they can help in clear cut identification of particular genotype [29]. Number of leaves (NL) and stem diameter (SD), were observed to be positive and highly significant between two groups; local and domesticated millet. Whereas very low variation was noted in third leave dimensions (LL and WL), and Panicle Wide (PW), where no significant difference was observed between local and domesticated millet. We present the main millet groups for Hoggar region based on the panicle form, color and dimensions (Figure 2 and Table 6).

\subsection{Cytological Parameters}

The standard millet descriptors of IBPGR and ICRISAT (1993), was used as a guide to take data, concerning the determination of Seed Number in Spikelet (SNS), position of Seed Envelop (SE), Seedcolors (SC) (Table 7). The cytological results of seeds show that, millet groups that have a high proportion of Corneous or Starchy endosperm (Figure 3 and Figure 4) are the preferred groups and have a high panicle nutritional value (MLH.Z $Z_{1}$, MLH.S and MDH. Saf), Unlike those of millet groups that have an intermediate endosperm proportion (MLH.N, MDH. Saf.P, MLD.Z $Z_{2}$ and MDH. SepL) (Table 8).

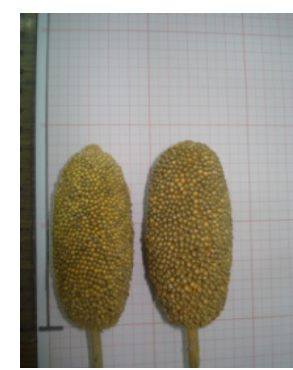

1-MLH.epc

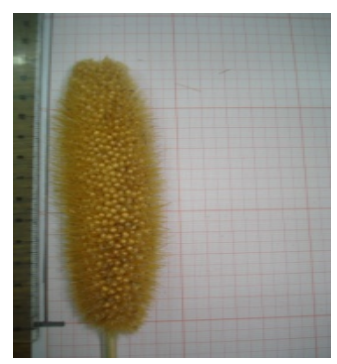

6-MDH.Saf.P

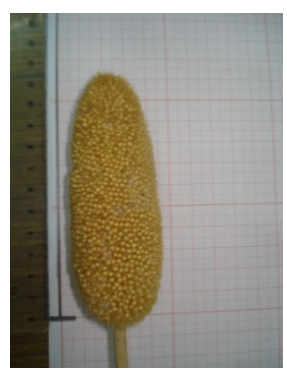

2-MLH.Saf

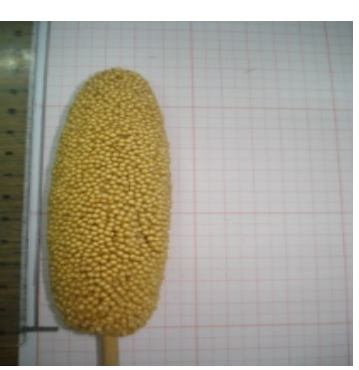

7-MDH.Saf

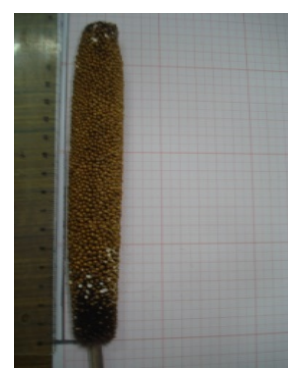

3-MLH.N

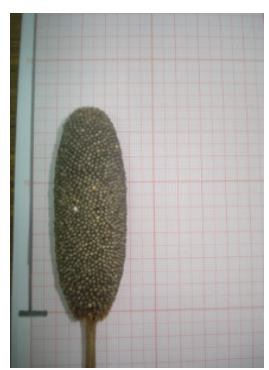

4-MLH. $\mathrm{Z}_{1}$

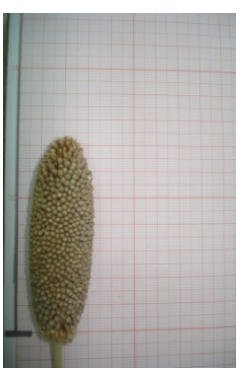

5-MLH.Z 2

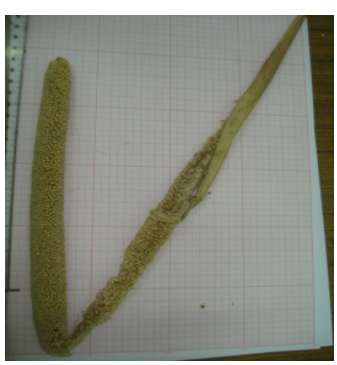

8-MDH.SepL

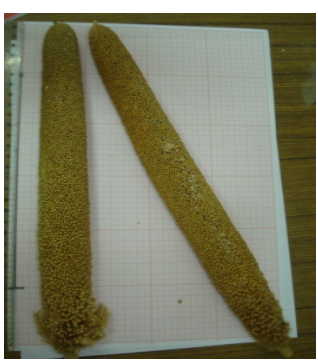

9-MDH.S

Figure 2. Different types of pearl millet panicles in plant maturation stage for Hoggar region.

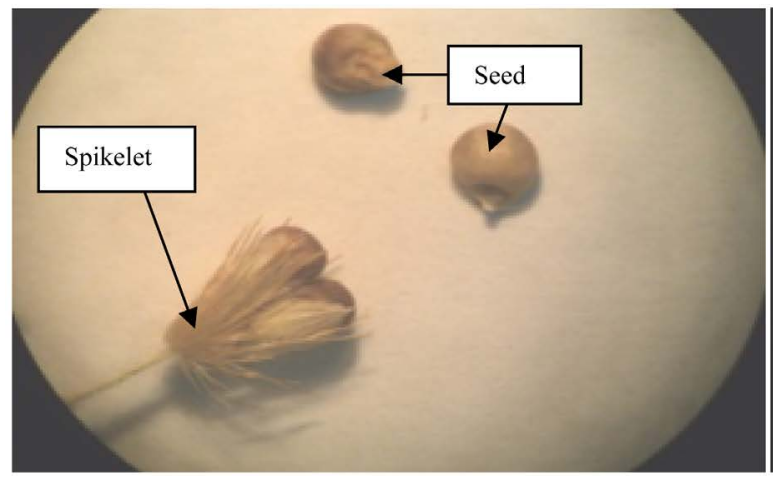

(a)

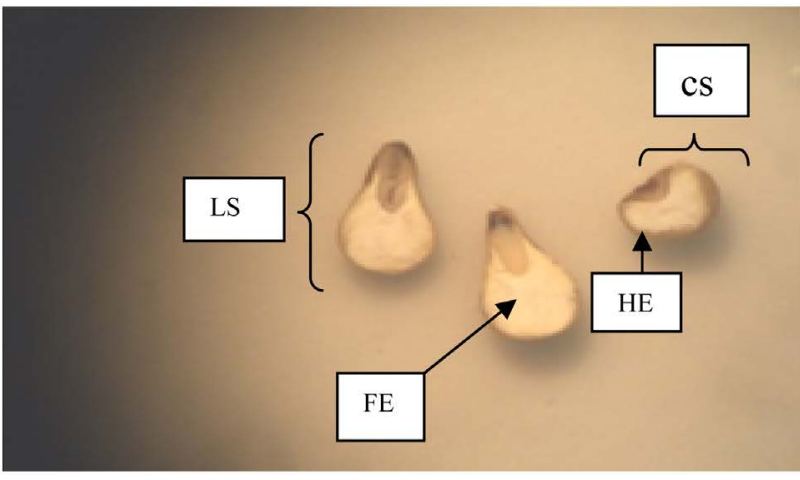

(b)

Figure 3. Local millet (MLH.epc). (a) Spikelet and seed; (b) Cross (CS) and longitudinal section (LS) in the seed. 


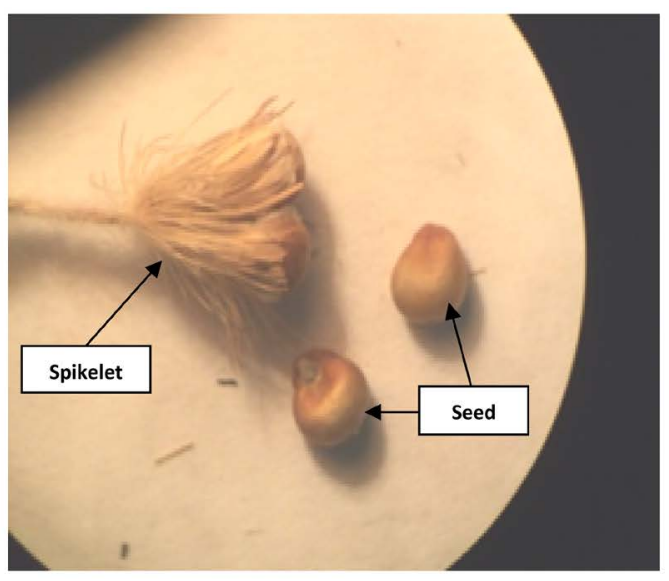

(a)

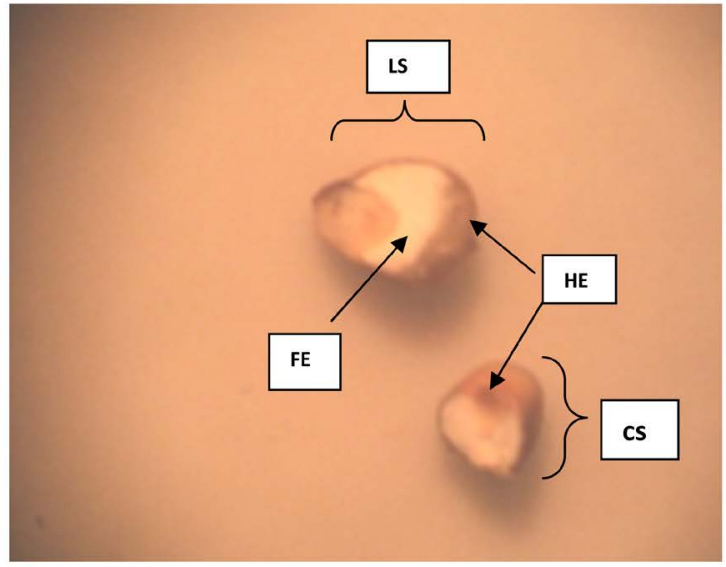

(b)

Figure 4. Domesticated millet (MDH.S). (a) Spikelet and seed; (b) CS and LS in the seed.

Table 6. Panicle characters of pearl millet groups in Hoggar region during the cropping season.

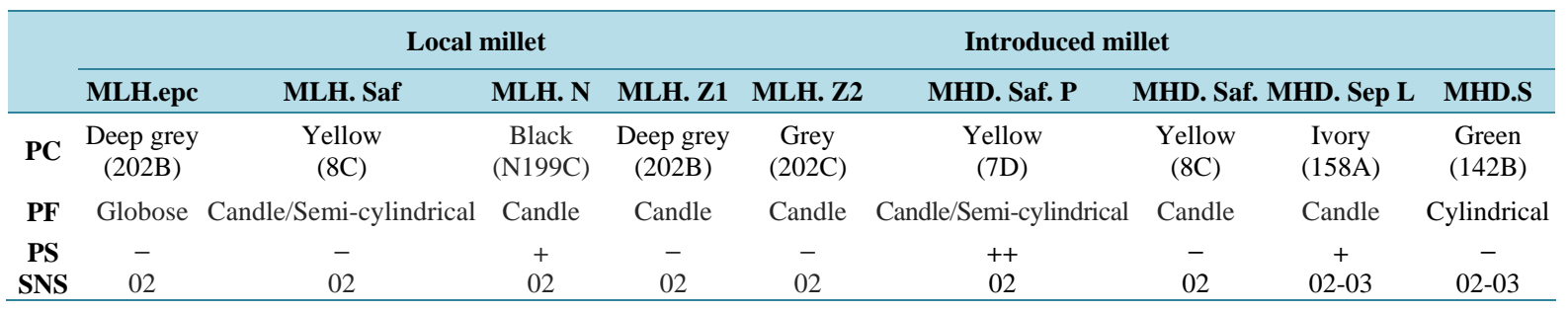

${ }^{+}$: Existence of PS, ${ }^{++}$: Existence of long PS, ${ }^{-}$: Absence of PS.

Table 7. Seeds characters of pearl millet groups in Hoggar region during the cropping season.

\begin{tabular}{|c|c|c|c|c|c|c|c|c|c|}
\hline & MLH.epc & MLH. Saf & MLH.N & MLH.Z 1 & MLH.Z 2 & MHD. Saf. P & MHD. Saf. & MHD. Sep L & MHD.S \\
\hline SE & $\begin{array}{l}\text { Exposed } \\
\text { (3) }\end{array}$ & $\begin{array}{l}\text { Exposed } \\
\text { (3) }\end{array}$ & $\begin{array}{l}\text { Intermediate } \\
\text { (5) }\end{array}$ & $\begin{array}{l}\text { Exposed } \\
\text { (3) }\end{array}$ & $\begin{array}{l}\text { Exposed } \\
\text { (3) }\end{array}$ & $\begin{array}{l}\text { Intermediate } \\
\text { (5) }\end{array}$ & $\begin{array}{l}\text { Exposed } \\
\text { (3) }\end{array}$ & $\begin{array}{c}\text { Enclosed } \\
\text { (7) }\end{array}$ & $\begin{array}{l}\text { Exposed } \\
\text { (3) }\end{array}$ \\
\hline SF & Obevate & Oblanceolate & Obevate & Oblanceolate & Oblanceolate & Globular & Globular & Obevate & Globular \\
\hline SC & $\begin{array}{l}\text { Deep grey } \\
\text { (202B) }\end{array}$ & $\begin{array}{c}\text { Yellow } \\
(8 C)\end{array}$ & $\begin{array}{c}\text { Black } \\
\text { (201A) }\end{array}$ & $\begin{array}{c}\text { Deep grey } \\
\text { (202B) }\end{array}$ & $\begin{array}{c}\text { Grey } \\
(202 \mathrm{C})\end{array}$ & $\begin{array}{l}\text { Yellow } \\
\text { (7D) }\end{array}$ & $\begin{array}{l}\text { Yellow } \\
(8 C)\end{array}$ & $\begin{array}{l}\text { Ivory } \\
\text { (158A) }\end{array}$ & $\begin{array}{l}\text { Green } \\
\text { (142B) }\end{array}$ \\
\hline $\begin{array}{l}\text { SW1L } \\
\text { (g) }\end{array}$ & $781.50 \pm 4.16$ & $781.50 \pm 4.56$ & $781.30 \pm 3.55$ & $782.60 \pm 2.81$ & 780.50 & 781.50 & $782.60 \pm 4.46$ & $781.60 \pm 3.55$ & 782.4 \\
\hline $\begin{array}{c}\text { TSW } \\
\text { (g) }\end{array}$ & $9.20 \pm 2.50$ & $9.20 \pm 0.70$ & $9.10 \pm 0.50$ & $9.40 \pm 0.14$ & $9.36 \pm 0.15$ & $9.76 \pm 0.15$ & $9.80 \pm 0.12$ & $7.50 \pm 0.04$ & $9.09 \pm 0.15$ \\
\hline
\end{tabular}

Table 8. Endosperm texture of Pearl millet seeds for Hoggar region.

\begin{tabular}{|c|c|c|c|c|c|}
\hline \multirow{2}{*}{$\mathbf{N}^{\circ}$} & \multirow{2}{*}{ Variable } & \multirow{2}{*}{ Moisture (\%) } & \multicolumn{3}{|c|}{ Endosperm texture (\%) } \\
\hline & & & Starchy & Intermediate & Corneous \\
\hline 1 & MLH.epc & 11.55 & 95 & 5 & 0 \\
\hline 2 & MLH. Saf & 11.41 & 95 & 5 & 0 \\
\hline 3 & MLH.N & 12.01 & 10 & 15 & 75 \\
\hline 4 & MLH.Z ${ }_{1}$ & 13.11 & 0 & 0 & 100 \\
\hline 5 & MLH.Z 2 & 12.66 & 0 & 10 & 90 \\
\hline 6 & MHD. Saf. P & 11.33 & 90 & 10 & 0 \\
\hline 7 & MHD. Saf & 10.00 & 96 & 4 & 0 \\
\hline 8 & MHD. SepL & 12.55 & 5 & 15 & 80 \\
\hline 9 & MHD.S & 11.13 & 15 & 5 & 80 \\
\hline
\end{tabular}




\section{Conclusion}

According to the investigation made about the morphological and cytological parameters of millet groups in the different studied sites on November 2008, 2010 and October 2011 in plant maturation stage, and the discussions with farmers interested for this kind of cereal culture, in addition to the observations on plant height, number of nodes, spike length and bristle length were recorded and the data were pooled over the locations; these could be grouped into distinct classes and could be useful for varietal identification and genetic purity testing. Based on standard descriptors, we distinguish generally, three main groups of pearl millet in this region [30]-[32].

\subsection{Local Millet Group}

Enélé ouan Ahaggar: Local pearl millet from Hoggar region, characterized by short height and very short blue panicle (MLH.Z $Z_{1}$ MLH.Z ${ }_{2}$ ) Zerga (Bleu) and medium height with yellow panicle (Saffra) (MLH.saf) and millet with short panicle (MLH.epc).

\subsection{Domesticated Millet Group (1)}

A-Enélé ouan Tidikelt: Local pearl millet from Tidikelt (Touat) region, characterized by short to medium stems (1.45 - $1.75 \mathrm{~m}$ ) with yellow panicles (MDH. Saf) sometimes hairy panicles (safra lamchaara (MDH. Saf. P).

B-Enélé ouan Djanét: Local pearl millet from Janet region has the same characters with the Tidikelt region millet.

\subsection{Domesticated Millet Group (2)}

This group locally named from their origin source, so we distinguish five principal subgroups:

A-Ineli Ouan Targa: Pearl millet introduced from Targa region, capital of Oubali in Libya, where habitant the Zintanes family in Targa valley this group of millet characterized by short $(5-10 \mathrm{~cm})$ and precocious panicles, with abundant Setae, and high nutritive value, blue gains, with legs texture of stems and leaves so, it's a good fodder for animals.

B-Ineli Ouan Agadés: Pearl millet introduced from Agade's region (Niger) this group of millet characterized by a long stem $(2-2.35 \mathrm{~m})$, long panicles too, $(40-55 \mathrm{~cm})$ grey-yellow color with abundant Setae (MDH.S).

C-Ineli Ouan Taboutqut: Pearl millet introduced from Taboutqut region (Niger), characterized by medium height plant and panicle too.

D-Ineli Ouan Damergou: Intrduced from Damergou region (Niger) this group of millet characterized by tardy panicles maturation, longue panicles (60 - $100 \mathrm{~cm}$ ) longue (MDH. SepL), yellow grains, their rough stems and long leaves too.

E-Ineli Ouan Tahoua: Introduced from Tahoua region (Niger), this millet characterized by long panicles (40 - $65 \mathrm{~cm}$ ), tardy maturation and yellow-light red grains, with rough stems and long leaves too, but less than Damergou group.

Following the codes provided by RHS, the Hoggar accessions exhibited five main panicle colors of, yellow, grey, deep-grey, green and black during the evaluation.

These results show that it is possible to select and improve forms (cultivars) according to local needs, based on morphological and cytological data of the plant, panicles and especially the structural characteristics of the seed. Despite its potential agronomic, especially drought tolerance and nutritional quality, millet continues to be marginalized in Algeria; this assessment is certainly a great contribution to enhancing the value of this cereal adapted in arid areas of Algeria. This study is assumed to identify the potential impact of local consumption in this region.

\section{Acknowledgements}

We are grateful to Hoggar local farmers. Especially, Nadjemi Hadj $\mathrm{M}^{\mathrm{ed}}$. and Hadji A. Familly. The members assembly municipal of In Amguel and Abalessa; $\mathbf{M}^{\mathrm{r}}$. Dahkhal, $\mathrm{M}^{\mathrm{r}}$. Ba Mhamed, for their help.

\section{References}

[1] FAO/ICRISAT (1996) The World Sorghum and Millet Economies: Facts, Trends and Outlook. FAO, Rome, Italy and 
ICRISAT, Patancheru, Andhra Pradesh, India, 68.

[2] Ndjeunga, J. and Nelson, C.H. (2005) Towards Understanding Household Preference for Consumption Characteristics of Millet Varieties: A Case Study from Western Niger. Agricultural Economics, 32, 151-165. http://dx.doi.org/10.1111/j.0169-5150.2005.00010.x

[3] Roden, P., Abraha, N., Debessai, M., Ghebreselassie, M., Beraki, H. and Kohler, T. (2007) Farmers’ Appraisal of Pearl Millet Varieties in Eritrea. Geographica Bernensia, Bern, 47.

[4] Tostain, S. (1998a) Le mil, une longue histoire: Hypothèses sur sa domestication et ses migrations. In: Chastanet, M., Ed., Plantes et paysages d'Afrique. Une histoire à explorer, Centre de Recherches Africaines, Paris, Chap. 16, 461490.

[5] Martel, E., De Nay, D., Siljak-Yakovlev, S., Brown, S. and Sarr, A. (1997) Genome Size Variation and Basic Chromosome Number in Pearl Millet and Fourteen Related Pennisetum Species. Journal of Heredity, 88, 139-143. http://dx.doi.org/10.1093/oxfordjournals.jhered.a023072

[6] Tostain, S. (1996) Genetic Diversity of Pearl Millet (Pennisetum glaucum) Estimated by Random Amplified DNA Markers and Compared with Isoenzymatic Diversity. Meeting on Tropical Plants, Montpellier, 11-15 March 1996, Communications \& Posters, CIRAD-MICAP, 255-256.

[7] Bilquez, A.I. and Lecomte, J. (1969) Relations entre mils sauvages et mils cultivés. Etude de l'hybride Pennesitum typhoides, Stapf et Hubb xpennesitum violaceum L. (Rich). Agronomie Tropical, 24, 249-257.

[8] Brunken, J.N., De Wet, J.M.J. and Harlan, J.R. (1977) The Morphology and Domestication of Pearl Millet. Economic Botany, 1, 163-174. http://dx.doi.org/10.1007/BF02866587

[9] Marchais, L., Tostain, S. and Amoukou, L. (1993) Signification taxonomique et évolutive dela structure génétique des mil s pénicillaires. ORsTOM, Paris, 119-128.

[10] Doeblejy, B.F., Goodman, M.M. and Stubecr, W. (1987) Patterns of Isozyme Variation between Maize and Mexican Annual Teosinte. Economic Botany, 41, 234-246. http://dx.doi.org/10.1007/BF02858971

[11] ONMT (Office National de la Météorologie de Tamanrasset) (2014) Document Interne.

[12] Tostain, S. and Daïnou, O. (1998) Bilan des collectes de Dioscorea abyssinica et de D. praehensilis, en 1996 et 1997 ; première étape d'un programme d'étude des relations entre ignames sauvages et ignames cultivées au Bénin. Poster. In: Berthaud, J., Bricas, N. and Marchand, J.-L., Eds., L'igname, Plante Séculaire et Culture d'avenir. Actes du Séminaire International Cirad-Inra-Orstom-Coraf, CIRAD, Montpellier, 257-258.

[13] Basavaraj, G., Parthasarathy Rao, P., Bhagavatula, S. and Ahmed, W. (2010) Availability and Utilization of Pearl Millet in India. Journal of SAT Agricultural Research, 8, 1-6.

[14] Ozenda, P. (1983) Flore du Sahara. CNRS, Paris, 622.

[15] Monod, T. (1957) Les grandes divisions de l’Afrique (Rapport présenté à la réunion des spécialistes sur la phytogéographie). Yacambi, 29 juillet-8 août 1956. Cons. Scien. Afr. Nord, Sahara. Londres, Royaume-Uni, Csa, 24, 147.

[16] Dubief, J. (1959) Le climat du Sahara. Mém. Inst. Rech. Sahara, 1, 312.

[17] Maire, R. (1933-1940) Étude sur la flore et la végétation du Sahara central. Mém. Soc. Nat. Afric.: 1re et 2e parties, 1933, N³, 1-272; 3e partie, 1940, 273-433.

[18] Celles, J.C. and Manière, R. (1980) Remarques sur la distribution en Afrique du Nord Occidentale d'Acacia seyal Delile et d'Acacia ehrenbergiana Hayne. Candolea, 37-70.

[19] Anonyme (2005) Bois et Forêts des Tropiques, № 284, 83.

[20] Vassal, J. (1972) Apport de recherches antigéniques et sémiologiques à l'étude morphologique, taxonomique et phytologique du genre Acacia. Bull. Soc. Hist. Nat., 108, 125-147.

[21] Andrews, D.J. and Kumar, K.A. (1992) Pearl Millet for Food, Feed and Forage. Advances in Agronomy, 48, 89-139. http://dx.doi.org/10.1016/S0065-2113(08)60936-0

[22] ICRISAT (1993) Descripteur du mil pénicillaire (Pennisetum glaucum (L.) R. Br.). Conseil International des Ressources Phytogénétiques. Rome, Italie; Institut International de Recherche sur les Cultures des Zones Tropicales Semi-arides, Patancheru, Inde.

[23] Taylor, J.R.N. and Taylor, J. (2008) Five Simple Methods for the Determination of Sorghum Grain End-Use Quality. 9-11. www.intsormil.org

[24] ICC. International Association for Cereal Science and Technology (2008) Estimation of Sorghum Grain Endosperm Texture. ICC Standard 176, Vienna.

[25] American Association of Cereal Chemists (2000) Approved Methods of the AACC. 10th Edition, Method 44-15A, the Association St. Paul, MN.

[26] Pale, S., Mason, S.C. and Galusha, T.D. (2003) Planting Time for Early-Season Pearl Millet and Grain Sorghum in 
Nebraska. Agronomy Journal, 95, 1047-1053. http://dx.doi.org/10.2134/agronj2003.1047

[27] Harris, D. (1996) The Effects of Manure, Genotypes, Seed Priming, Depth and Date of Sowing on the Emergence and Early Growth of Sorghum bicolor (L.) Moench in Semi-Arid Botswana. Soil and Tillage Research, 40, 73-88.

[28] Teare, I.D., Wright, D.L. and Pudelko, J.A. (1993) Physiological Development of HGM-100 to Planting Date and Available Water. Fla. Agric. Exp. Stn. Res. Rap, No. NF-92-5, 1-17.

[29] Gupta, S.K., Bhattacharjee, R., Rai, K.N. and Suresh Kumar, M. (2011) Characterization of ICRISAT-Bred Restorer Parents of Pearl Millet. Journal of SAT Agricultural Research, 9, 1-5.

[30] BRG. Bureau des Ressources Génétiques (1993) Sauve qui peut, Inra, № 5, 59.

[31] Marceau, G. and Adrian, J. (1965) Mil et Sorgho en Ahaggar. Achevé d’imprimer sur les presses de la S.R.I.P., Paris.

[32] Quezel, P. (1954) Contribution à l'étude de la flore et de la végétation du Hoggar. Monographies régionales 2. Trav. Inst. Rech. Sahara, 164. 


\section{Appendix}

Analysis of Variance (ANOVA)

\begin{tabular}{|c|c|c|c|c|c|c|}
\hline & & Sum of Squares & df & Mean Square & $\mathrm{F}$ & Sig. \\
\hline \multirow{3}{*}{ HP } & Between Groups & 0.000 & 1 & 0.000 & 0.000 & 0.985 \\
\hline & Within Groups & 0.518 & 7 & 0.074 & & \\
\hline & Total & 0.518 & 8 & & & \\
\hline \multirow{3}{*}{$\mathrm{NN}$} & Between Groups & 0.513 & 1 & 0.513 & 0.404 & 0.545 \\
\hline & Within Groups & 8.896 & 7 & 1271 & & \\
\hline & Total & 9.409 & 8 & & & \\
\hline \multirow{3}{*}{ NL } & Between Groups & 2.387 & 1 & 2.387 & 1.438 & 0.270 \\
\hline & Within Groups & 11.623 & 7 & 1.660 & & \\
\hline & Total & 14.011 & 8 & & & \\
\hline \multirow{3}{*}{ SD } & Between Groups & 8.791 & 1 & 8.791 & 1.368 & 0.281 \\
\hline & Within Groups & 44.999 & 7 & 6.428 & & \\
\hline & Total & 53.790 & 8 & & & \\
\hline \multirow{3}{*}{ PL } & Between Groups & 413.868 & 1 & 413.868 & 3.594 & 0.100 \\
\hline & Within Groups & 806.057 & 7 & 115.151 & & \\
\hline & Total & 1219.925 & 8 & & & \\
\hline \multirow{3}{*}{ PW } & Between Groups & 261.678 & 1 & 261.678 & 1.835 & 0.218 \\
\hline & Within Groups & 998.403 & 7 & 142.629 & & \\
\hline & Total & 1260.081 & 8 & & & \\
\hline \multirow{3}{*}{ L.3L } & Between Groups & 4.328 & 1 & 4.328 & 0.126 & 0.733 \\
\hline & Within Groups & 240.145 & 7 & 34.306 & & \\
\hline & Total & 244.472 & 8 & & & \\
\hline \multirow{3}{*}{ W.3L } & Between Groups & 83.314 & 1 & 83.314 & 1.533 & 0.256 \\
\hline & Within Groups & 380.314 & 7 & 54.331 & & \\
\hline & Total & 463.628 & 8 & & & \\
\hline
\end{tabular}

Take into account the Sig. $<0.05$.

Dendrogram using Ward Method

\section{Rescaled Distance Cluster Combine}

C A S E

0

5

10

15

20

25

LabelNum
MLH . Z1

MLH. Z2

MHD.Saf.P6 -+---+

MHD.Saf

MLH. Saf

MLH . epc

$\mathrm{MLH} . \mathrm{N}$

MHD.SepL 8

MHD.S

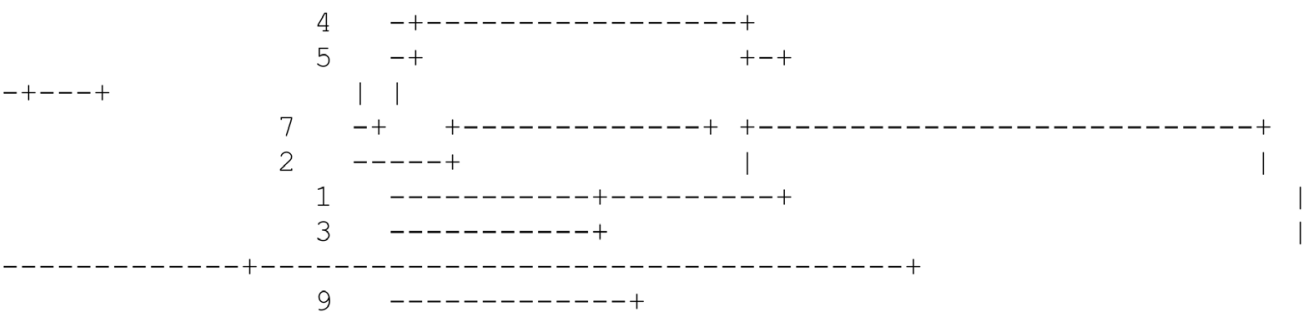




\section{HIERARCHICAL CLUSTER ANALYSIS}

Descriptive

\begin{tabular}{|c|c|c|c|c|c|c|c|c|c|}
\hline & & & & & & 95\% Confiden & erval for Mean & & \\
\hline & & $1 \mathrm{v}$ & MVIedil & stu. Deviduon & Stu. ЕIIU & Lower Bound & Upper Bound & 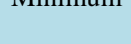 & IVaxımum \\
\hline & loc & 5 & 1.4340 & 0.14792 & 0.06615 & 1.2503 & 1.6177 & 1.28 & 1.64 \\
\hline HP & dom & 4 & 1.4375 & 0.37880 & 0.18940 & 0.8347 & 2.0403 & 1.10 & 1.79 \\
\hline & Total & 9 & 1.4356 & 0.25447 & 0.08482 & 1.2400 & 1.6312 & 1.10 & 1.79 \\
\hline & loc & 5 & 8.8320 & 0.55328 & 0.24743 & 8.1450 & 9.5190 & 8.00 & 9.50 \\
\hline $\mathrm{NN}$ & dom & 4 & 9.3125 & 1.59915 & 0.79958 & 6.7679 & 11.8571 & 8.00 & 11.25 \\
\hline & Total & 9 & 9.0456 & 1.08452 & 0.36151 & 8.2119 & 9.8792 & 8.00 & 11.25 \\
\hline & loc & 5 & 9.5660 & 0.43506 & 0.19457 & 9.0258 & 10.1062 & 9.00 & 10.00 \\
\hline NL & dom & 4 & 10.6025 & 1.90316 & 0.95158 & 7.5741 & 13.6309 & 9.00 & 12.75 \\
\hline & Total & 9 & 10.0267 & 1.32338 & 0.44113 & 9.0094 & 11.0439 & 9.00 & 12.75 \\
\hline & loc & 5 & 9.7760 & 1.70086 & 0.76065 & 7.6641 & 11.8879 & 8.24 & 12.36 \\
\hline SD & dom & 4 & 11.7650 & 3.33801 & 1.66900 & 6.4535 & 17.0765 & 9.50 & 16.64 \\
\hline & Total & 9 & 10.6600 & 2.59302 & .86434 & 8.6668 & 12.6532 & 8.24 & 16.64 \\
\hline & loc & 5 & 10.2580 & 2.94516 & 1.31712 & 6.6011 & 13.9149 & 7.14 & 13.11 \\
\hline PL & dom & 4 & 23.9050 & 16.03497 & 8.01749 & -1.6102 & 49.4202 & 11.96 & 46.00 \\
\hline & Total & 9 & 16.3233 & 12.34871 & 4.11624 & 6.8313 & 25.8154 & 7.14 & 46.00 \\
\hline & loc & 5 & 31.2860 & 9.90034 & 4.42757 & 18.9931 & 43.5789 & 22.12 & 46.01 \\
\hline PW & dom & 4 & 42.1375 & 14.21661 & 7.10830 & 19.5157 & 64.7593 & 31.11 & 61.73 \\
\hline & Total & 9 & 36.1089 & 12.55030 & 4.18343 & 26.4619 & 45.7559 & 22.12 & 61.73 \\
\hline & loc & 5 & 39.5120 & 4.51486 & 2.01911 & 33.9061 & 45.1179 & 36.12 & 46.94 \\
\hline L.3L & dom & 4 & 40.9075 & 7.27115 & 3.63558 & 29.3375 & 52.4775 & 34.14 & 47.55 \\
\hline & Total & 9 & 40.1322 & 5.52802 & 1.84267 & 35.8830 & 44.3814 & 34.14 & 47.55 \\
\hline & loc & 5 & 29.9020 & 6.20537 & 2.77513 & 22.1970 & 37.6070 & 23.46 & 38.28 \\
\hline W.3L & dom & 4 & 36.0250 & 8.68500 & 4.34250 & 22.2052 & 49.8448 & 28.80 & 47.20 \\
\hline & Total & 9 & 32.6233 & 7.61272 & 2.53757 & 26.7717 & 38.4750 & 23.46 & 47.20 \\
\hline
\end{tabular}

Total Variance Explained

\begin{tabular}{ccccccc}
\hline \multirow{2}{*}{ Component } & \multicolumn{3}{c}{ Initial Eigenvalues } & \multicolumn{2}{c}{ Extraction Sums of Squared Loadings } \\
\cline { 2 - 6 } & Total & \% of Variance & Cumulative \% & Total & \% of Variance & Cumulative \% \\
\hline 1 & 6.083 & 76.037 & 76.037 & 6.083 & 76.037 & 76.037 \\
2 & 0.772 & 9.650 & 85.686 & & \\
3 & 0.640 & 8.006 & 93.692 & & \\
4 & 0.329 & 4.108 & 97.800 & & \\
5 & 0.156 & 1.945 & 99.745 & & \\
7 & 0.020 & 0.251 & 99.996 & & \\
8 & 0.000 & 0.003 & 99.999 & & \\
\hline
\end{tabular}

Extraction Method: Principal Component Analysis. 


\section{Submit or recommend next manuscript to SCIRP and we will provide best service for you:}

Accepting pre-submission inquiries through Email, Facebook, LinkedIn, Twitter, etc.

A wide selection of journals (inclusive of 9 subjects, more than 200 journals)

Providing 24-hour high-quality service

User-friendly online submission system

Fair and swift peer-review system

Efficient typesetting and proofreading procedure

Display of the result of downloads and visits, as well as the number of cited articles

Maximum dissemination of your research work

Submit your manuscript at: http://papersubmission.scirp.org/ 